\title{
5 $\alpha$-dihydrotestosterone reduces renal Cyp24a1 expression via suppression of progesterone receptor
}

\author{
Sang R Lee', Mi-Young Park', Hyun Yang², Geun-Shik Lee ${ }^{3}$ Beum-Soo An4, Bae-kuen Park', Eui-Bae Jeung ${ }^{5}$ and \\ Eui-Ju Hong'
}

'College of Veterinary Medicine, Chungnam National University, Daejeon, Republic of Korea

${ }^{2}$ Korean Institute of Oriental Medicine, Daejeon, Republic of Korea

${ }^{3}$ College of Veterinary Medicine, Kangwon National University, Chuncheon, Gangwon, Republic of Korea

${ }^{4}$ Department of Biomaterials Science, College of Natural Resources \& Life Science, Pusan National University, Miryang, Republic of Korea

${ }^{5}$ College of Veterinary Medicine, Chungbuk National University, Cheongju, Chungbuk, Republic of Korea

Correspondence should be addressed to E-J Hong: ejhong@cnu.ac.kr

\begin{abstract}
Androgens act in concert with vitamin $D$ to influence reabsorption of calcium. However, it is unclear whether androgens directly regulate vitamin $\mathrm{D}$ homeostasis or control other cellular events that are related to vitamin D metabolism. To examine whether the expression of vitamin D-related genes in mouse kidney is driven by androgens or androgen-dependent effects, the androgen receptor and other sex steroid receptors were monitored in orchidectomized mice treated with $5 \alpha$-dihydrotestosterone (DHT). Our results revealed that exposing orchidectomized mice to DHT inhibited the expression of progesterone receptor (Pgr) with or without estrogen receptor $\alpha$ expression, the latter was confirmed by ER-positive (MCF7 and T47D) or -negative (PCT) cells analysis. The loss of Pgr in turn decreased the expression of renal 24-hydroxylase via transcriptional regulation because Cyp24a1 gene has a progesterone receptor-binding site on promoter. When male kidneys preferentially hydroxylate 25-hydroxyvitamin $D_{3}$ using 24-hydroxylase rather than 25-hydroxyvitamin $\mathrm{D}_{3}$-1-alpha hydroxylase, DHT suppressed the Pgrmediated 24-hydroxylase expression, and it is important to note that DHT increased the blood 25-hydroxyvitamin $\mathrm{D}_{3}$ levels. These findings uncover an important link between androgens and vitamin $\mathrm{D}$ homeostasis and suggest that therapeutic modulation of Pgr may be used to treat vitamin $\mathrm{D}$ deficiency and related disorders.
\end{abstract}
Key Words
- $5 \alpha$-dihydrotestosterone
- kidney
- androgen withdrawal
- Cyp24a1
- progesterone receptor
- renal tubule cells

\section{Introduction}

Androgens perform physiologically essential functions in the development and differentiation of the male reproductive tract, but their anabolic effects are also seen in non-reproductive tissues (Bardin \& Catterall 1981). For instance, androgens increase the life span of bone cells through anti-apoptotic activity (Kasperk et al.
1989), and their effects are linked with transcriptional activity of the androgen receptor (Kousteni et al. 2001). Androgens induce both cell proliferation and hypertrophy in the prostate, whereas they are only involved in cell hypertrophy in the kidney (Catterall et al. 1986). Although kidneys do not require androgens 
for normal functions (Catterall et al. 1986), it is possible that androgens have a significant role in the homeostasis of the body. While estrogen deficiency has been shown to be involved in the osteoporosis related to calcium and vitamin D (Morris et al. 2010), studies have also indicated that androgens can act in concert with vitamin $\mathrm{D}$ to influence important physiological events including mobilization of bone calcium (Greenspan et al. 2005) and UV light-induced vitamin D production in the skin (Xue et al. 2015). In patients afflicted with coronary artery disease, levels of 25-hydroxyvitamin D (calcidiol) in the blood were found to be much greater in men than that in women (Verdoia et al. 2015). Interestingly, obese men were more prone to vitamin D deficiency when compared to women (Johnson et al. 2012). Increased aromatase activity in obese individuals evidently reduces levels of androstenedione by converting it to estrone in adipose tissues (Zumoff 1982). Another study suggests a link between the impairment of testicular function and low levels of 25-hydroxyvitamin $\mathrm{D}_{3}$; vitamin D-deficient male rat has an insufficient fertility, such as sperm concentration, sperm morphology and motile sperm count (Kwiecinski et al. 1989). As a mediator for local vitamin D production, 25-hydroxylase CYP2R1 has been detected in testes and Leydig cells producing androgen (Bieche et al. 2007, Foresta et al. 2011). These findings highlight the need for further studies on the cellular functions of androgen in relation to vitamin D metabolism. There is also considerable evidence that the imbalance in calcium homeostasis may originate from sex steroid hormone deprivation or vitamin $\mathrm{D}$ disorder and from declining calcium reabsorption efficiency in the kidney due to aging. For instance, renal vitamin D receptor $(V D R)$ expression correlates inversely with serum sex steroid levels (Iida et al. 1995), while estrogen influences the expression of enzymes involved in $1 \alpha, 25$-dihydroxyvitamin $\mathrm{D}_{3}$ (calcitriol) production and metabolism (Lechner et al. 2006).

As the major circulating vitamin $\mathrm{D}$ metabolite in the body, 25-hydroxyvitamin $\mathrm{D}_{3}$ is synthesized in the liver by 25 -hydroxylase enzymes such as 25 -hydroxylase CYP27A1 or CYP2R1 (Zhu et al. 2013). The converted 25-hydroxyvitamin $\mathrm{D}_{3}$ is endogenously activated by 25-hydroxyvitamin $\mathrm{D}_{3}-1 \alpha$ hydroxylase (CYP27B1) at the $1 \alpha$ position in the renal cortex, which gives rise to the active form of vitamin $\mathrm{D}, 1 \alpha, 25$-dihydroxyvitamin $\mathrm{D}_{3}$ (Jones et al. 1998). Both 25-hydroxyvitamin $\mathrm{D}_{3}$ and $1 \alpha, 25$-dihydroxyvitamin $\mathrm{D}_{3}$ can be further hydroxylated by the vitamin D-inactivating enzyme, 24-hydroxylase (CYP24A1). $1 \alpha, 25$-dihydroxyvitamin $\mathrm{D}_{3}$ plays a major role in regulating calcium homeostasis. Low levels of $1 \alpha, 25$ dihydroxyvitamin $\mathrm{D}_{3}$ increase the release of parathyroid hormone that stimulates CYP27B1 expression, while high levels of $1 \alpha, 25$-dihydroxyvitamin $\mathrm{D}_{3}$ induce CYP24A1 expression (Jones et al. 1998). In addition to its role in vitamin D homeostasis, CYP24A1 may be implicated in cancer, as overexpression of CYP24A1 has been noted in several tumors including lung, breast colon cervical and ovarian cancer (Deeb et al. 2007). When vitamin D3 used as an antitumor agent in patients with prostate cancer, CYP24A1 is also used as a predictive marker of vitamin D3-based therapies (Tannour-Louet et al. 2014). In early studies, $5 \alpha$-dihydrotestosterone (DHT) has been shown to significantly inhibit the expression of Cyp24a1 mRNA in a prostate cancer cell line (Lou et al. 2005). However, little is known about the mechanism underlying the regulation of CYP24A1 expression by androgens.

The kidney is well recognized as an androgen target organ, where various overexpressed genes resulting from androgen exposure have been identified (Berger \& Watson 1989). Interestingly, it is also established that CYP27A1 and CYP24A1 are mainly localized in the proximal convoluted tubule of the kidney (Kurokawa et al. 1982). To examine whether the expression of vitamin D-related genes is affected by androgens, levels of transcripts corresponding to the androgen- and vitamin D-related genes were monitored in the mouse kidney and in the immortalized PKSV-PCT mouse proximal convoluted tubule (PCT) epithelial cell line, which has characteristics of epithelial cells in the S1-S2 region of the proximal convoluted tubule (Cartier et al. 1993) and expresses the Kap gene in response to androgen (Soler et al. 2002). Interestingly, we observed that androgen suppresses the expression of Cyp24a1 mRNA without affecting the expression of vitamin D receptor $(V d r)$ and that the reduced Cyp24a1 level is correlated with reduced expression of progesterone receptor. Our work highlights the complexity of androgen actions in vitamin D catabolism.

\section{Materials and methods}

\section{Animals and treatment}

Male mice in a C57BL/6N background obtained from Orient Bio (Seongnam, Korea) and were housed in a pathogen-free facility at Chungnam National University under a standard 12-h light:12-h darkness cycle and fed standard chow with water provided ad libitum. All mouse experiments were performed in accordance with the Chungnam Facility Animal Care Committee 
(CNU-00606). To remove endogenous androgen, 6-weekold mice were subjected to surgical orchiectomy. They are separated for treatment group (each group, $n=5$ or 6 ). After 2 weeks post surgery, mice were treated for 5 days with either DHT $(50 \mu \mathrm{g} /$ day; A8380; Sigma-Aldrich) or bicalutamide (1 mg/day; B9061; Sigma-Aldrich) in a corn oil solution by subcutaneous injection, and then kidneys were isolated at $24 \mathrm{~h}$ following final injection. For analysis, all mice were killed with $\mathrm{CO}_{2}$ asphyxiation.

\section{Cell culture}

All cell culture reagents were from Life Technologies. The T47D and MCF7 breast cancer cells grown at $37^{\circ} \mathrm{C}$ in a $5 \% \mathrm{CO}_{2}$ atmosphere in DMEM medium supplemented with $10 \%$ fetal bovine serum, penicillin $(100 \mathrm{U} / \mathrm{mol})$ and streptomycin $(100 \mu \mathrm{g} / \mathrm{mL})$. The PKSV-PCT (PCT) cell line was kindly provided by Dr A. Vandewalle (INSERM U478, Paris, France) and grown at $37^{\circ} \mathrm{C}$ in a $5 \% \mathrm{CO}_{2}$ atmosphere in DMEM/F12 medium supplemented with $2 \%$ fetal bovine serum, insulin $(5 \mu \mathrm{g} / \mathrm{mL})$, dexamethasone $\left(5 \times 10^{-8} \mathrm{M}\right)$, selenium $(60 \mathrm{nM})$, transferrin $(5 \mu \mathrm{g} / \mathrm{mL})$, triiodothyronine $\left(5 \times 10^{-8} \mathrm{M}\right)$, EGF $(10 \mathrm{ng} / \mathrm{mL})$, D-glucose $(20 \mathrm{mM})$, penicillin $(100 \mathrm{U} / \mathrm{mol})$ and streptomycin $(100 \mu \mathrm{g} / \mathrm{mL})$.

\section{Gene knockdown and gene overexpression assay}

Briefly, $4 \times 105$ PCT cells were seeded into six-well tissue culture plates 1 day before transfection in $2 \mathrm{~mL}$ phenol redfree DMEM/F12 medium (Life Technologies) containing $2 \%$ dextran charcoal-treated fetal bovine serum (Thermo Fisher Scientific). Transient transfection of $P R a$ or $P R b$ expression vectors $(5 \mu \mathrm{g})$, and a $P G R$ siRNA (Qiagen Flexitube gene Solution; Qiagen Korea) were performed using lipofectamine reagent (Life Technologies) according to the protocol recommended by Life Technologies. At $24 \mathrm{~h}$ after transfection, the cells were washed twice with PBS and harvested by scraping. After centrifugation, cell pellets were re-suspended in $100 \mu \mathrm{L} 0.25 \mathrm{M}$ Tris-Cl, pH 7.8, and cells were lysed by 3 freeze-thaw cycles.

\section{Western blotting}

Cell and kidney samples were homogenized in lysis buffer (10 mM Tris, $\mathrm{pH} 7.5,150 \mathrm{mM} \mathrm{NaCl}, 1 \%$ Triton X-100, $1 \mathrm{mM}$ phenylmethylsulfonyl fluoride, $0.2 \mathrm{mM}$ sodium orthovanadate, $0.5 \%$ Nonidet P-40 containing protease inhibitor phenylmethylsulfonyl fluoride (P7626; SigmaAldrich) at $4^{\circ} \mathrm{C}$ for $30 \mathrm{~min}$. Protein was quantified using the Bradford assay PRO-MEASURE (Intron Biotechnology,
Sungnam, Korea) and proteins were resolved on 7.5$10 \%$ SDS-PAGE gels. The membranes were blocked for $1 \mathrm{~h}$ in PBS containing 0.1\% Tween 20 (PBS-T) and 5\% skim milk and then incubated overnight at $4^{\circ} \mathrm{C}$ with a primary antibody (see below) in the same buffer. The blots were then washed three times in PBS-T for $15 \mathrm{~min}$ to remove excess antibody and then the membranes were incubated for $1 \mathrm{~h}$ with secondary antibodies in PBS-T+5\% skim: anti-rabbit (bs-0295G-HRP; MA, USA or 211-032-171; Jackson Laboratories) or anti-mouse (115035-174; Jackson Laboratories). Following 3 washes in PBS-T, proteins were detected using Lumi-Light Western blotting substrate (Roche Korea). Primary antibodies used were progesterone receptor (sc-7208; Santa Cruz Biotechnology), CYP24A1 (ab175976; Abcam), VDR (sc9164; Santa Cruz Biotechnology), CYP27B1 (sc-67260; Santa Cruz Biotechnology) and actin (sc-1616; Santa Cruz Biotechnology).

\section{ChIP assay using progesterone receptor}

ChIP was used to measure the association of progesterone receptor with bound genes. As previously described (Hong et al. 2013), ChIP samples from murine PCT cells were prepared with cell culture medium containing formaldehyde (1\% final), and DNA-protein crosslinking was allowed to occur at room temperature for $10 \mathrm{~min}$ with rotation. The crosslinked cells were washed twice with cold PBS and re-suspended in nuclei lysis buffer (50 mM Tris- $\mathrm{HCl}, \mathrm{pH} 8.1,10 \mathrm{mM}$ EDTA, 1\% SDS) supplemented with protease inhibitors (Roche Korea). Samples were sonicated on ice at power 10 for 30 s pulses using a VirSonic 100 (Virtis) sonicator at 30s intervals to prevent the samples from heating. Sonicated material was centrifuged at $16,200 \boldsymbol{g}$ for $15 \mathrm{~min}$ at $4^{\circ} \mathrm{C}$ to remove cellular debris, and chromatin $(100 \mu \mathrm{g})$ was diluted in $2.5 \mathrm{X}$ ChIP dilution buffer $(0.5 \%$ Triton X-100, 2 mM EDTA, $100 \mathrm{mM}$ $\mathrm{NaCl}, 20 \mathrm{mM}$ Tris- $\mathrm{HCl}, \mathrm{pH}$ 8.1) and incubated overnight with anti-PR polyclonal antibody (sc-7208; Santa Cruz Biotechnology) or a rabbit IgG antibody as a control (sc2027; Santa Cruz Biotechnology) and $60 \mu \mathrm{L}$ of Dynabeads Protein A (10008D; Life Technologies). Beads were washed 6 times with $\mathrm{LiCl}$ buffer (1\% NP-40, $500 \mathrm{mM} \mathrm{LiCl,} 1 \%$ Na-deoxycholate, $\mathrm{pH} 8.0,100 \mathrm{mM}$ Tris-HCl, $\mathrm{pH}$ 8.1). The beads were next washed briefly with TE buffer (10 mM Tris$\mathrm{HCl}, \mathrm{pH} 7.5,1 \mathrm{mM}$ EDTA, $\mathrm{pH}$ 8.0) and de-crosslinked (1\% SDS, $0.1 \mathrm{M} \mathrm{NaHCO}_{3}$ ) at $65^{\circ} \mathrm{C}$ overnight. De-crosslinked samples were purified using the QIAquick Spin Kit (Qiagen Korea). PGR standard ChIP enrichments were quantified by qPCR analysis using specific primers and normalized to 
the average enrichments obtained using 2 control primer sets amplifying non-PGR bound genomic regions.

\section{Total RNA extraction and quantitative real-time PCR}

Total RNA extracts from mouse kidney or PCT cells were prepared using the TRIzol Reagent (Thermo Fisher Scientific). Reverse transcription was performed at $37^{\circ} \mathrm{C}$ for $60 \mathrm{~min}$ using $1 \mu \mathrm{g}$ of total RNA and 200 units of M-MLV together (Intron Biotechnology) with random primers and reagents provided by Thermo Fisher Scientific. Quantitative RT-PCR was carried out using specific primers (Table 1), a SYBR Premix Ex Taq (TakaraClontech Laboratories) and a CFX Connect Real-Time PCR Detection System (Bio-Rad) equipped with a 96-well optical reaction plate. Negative controls, containing water instead of sample cDNA, were used in each plate. All experiments were run in triplicate, and mRNA values were calculated based on the cycle threshold and monitored for an amplification curve.

\section{ELISA}

Circulating 25-hydroxyvitamin D levels were detected in serum from naïve or orchidectomized mice acutely treated with DHT for the indicated time points. Enzyme-linked immunosorbent assay (ELISA) kits were obtained from IBL international GMBH (IBL International, Hamburg, Germany), the serum levels of 25-hydroxyvitamin D3 levels were measured according to the manufacturer's protocols, and absorbance was determined at $450 \mathrm{~nm}$ using a microplate ELISA reader (Bio-Rad).

\section{Data analysis}

Data were analyzed using one-way and two-way analysis of variance (ANOVA) followed by Tukey's multiple comparison test and presented as the mean \pm s.E.M. using Prism Graph Pad (v4.0; GraphPad Software). $P$ values $<0.05$ were considered statistically significant.

\section{Results}

\section{Identification of androgen response genes whose expression is either enhanced or suppressed by the presence of DHT}

To assess whether endogenous androgens influence sex steroid hormone-mediated actions, we first performed surgical castration (orchiectomy) on male mice. After removal of the principal source for endogenous androgen production, mice were treated with DHT $(50 \mu \mathrm{g} /$ day $)$ or DHT-bicalutamide-treated $(1 \mathrm{mg} /$ day $)$ for 5 days. We observed clear decreases in Kap mRNA levels in the kidneys of all orchiectomy groups when compared to the corresponding sham-operated control groups (Fig. 1A). We noted that the synthesis rate of Kap mRNA could be maintained by small amounts of residual testosterone as shown in a previous study (Watson \& Paigen 1988), which in turn confirmed that the orchidectomized mice were still responsive to androgens. In the absence of endogenous androgens, DHT treatment induced the expression of Kap mRNA, while DHT-induced Kap mRNA levels were significantly inhibited by androgen receptor (Ar) blocker, bicalutamide (Fig. 1A). To further investigate, we then monitored the levels of mRNA corresponding to the androgen, estrogen, and progesterone receptors.

Table 1 Primers used for real-time or conventional PCR, related to Figs 1, 2, 3, 4 and 5.

\begin{tabular}{l} 
Gene name \\
\hline$K a p$ \\
Ar \\
ESr1 \\
Pgr \\
VDR \\
Cyp24a1 \\
Cyp27b1 \\
Gapdh \\
AR \\
ESR1 \\
PGR \\
GAPDH \\
Cyp24a1 \\
Pgr \\
Ppargc1a \\
Sox17
\end{tabular}

\begin{tabular}{l} 
Upper primer $\left(5^{\prime}-3^{\prime}\right)$ \\
\hline TTCTGTGGTCTGACTGTGGC \\
CTGGGAAGGGTCTACCCAC \\
TGTGTCCAGCTACAAACCAATG \\
CTCCGGGACCGAACAGAGT \\
ACCCTGGTGACTTTGACCG \\
CTGCCCCATTGACAAAAGGC \\
GCACAGTTTACGTTGCCGAC \\
GCTGAGTATGTCGTGGAGTC \\
GACGACCAGATGGCTGTCATT \\
CCCACTCAACAGCGTGTCTC \\
ACCCGCCCTATCTCAACTACC \\
GGAGCGAGATCCCTCCAAAAT \\
GCACAGCCTCTGATGTTTCA \\
GAGCCTGGTTACTGCAAAGG \\
CCGGCAACCTAGAACACAGT \\
TCTCACCTGGCTTCTCTGCT
\end{tabular}

Lower primer $\left(5^{\prime}-3^{\prime}\right)$

CGTGAAGTCCATGATCTGCT

GGTGCTATGTTAGCGGCCTC CATCATGCCCACTTCGTAACA

ACAACAACCCTTTGGTAGCAG

GGCAATCTCCATTGAAGGGG

CTCACCGTCGGTCATCAGC

CGTTAGCAATCCGCAAGCA

TTGGTGGTGCAGGATGCATT

GGGCGAAGTAGAGCATCCT

CGTCGATTATCTGAATTTGGCCT

AGGACACCATAATGACAGCCT

GGCTGTTGTCATACTTCTCATGG

AGCTCTGGACTTTTCCACCA

CGACATTCTGGGACTCATCC

CAGCATAGCCCTCTCCAGTC

TCCCATGCCTTTATTTCTGG

\begin{tabular}{l}
\hline Species \\
\hline Mouse \\
Mouse \\
Mouse \\
Mouse \\
Mouse \\
Mouse \\
Mouse \\
Mouse \\
Human \\
Human \\
Human \\
Human \\
ChIP \\
ChIP \\
ChIP \\
ChIP
\end{tabular}


$A$

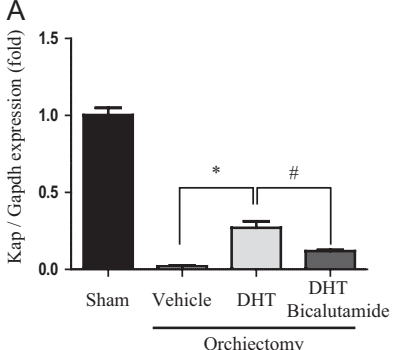

C

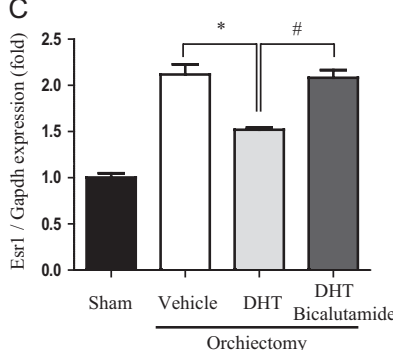

Figure 1

Influence of $5 \alpha$-dihydrotestosterone (DHT) on sex steroid receptors in kidney. After orchiectomy and recovery of mice for 2 weeks, male mice ( $n=5$ or 6 per each group) were treated with vehicle alone (vehicle), with DHT $(50 \mu \mathrm{g} /$ day) or DHT plus bicalutamide $(1 \mathrm{mg} /$ day $)$ for 5 days, and Kap (A), $\operatorname{Ar}(B), E s r 1$ (C) and Pgr (D) mRNA levels were determined by quantitative RT-PCR. Gapdh mRNA was used as in internal control. Values represent means \pm S.E.M. ${ }^{*} P<0.05$ vs orchiectomy vehicle-alone (control) treated group. ${ }^{\# P}<0.05$ vs DHT-bicalutamide-treated group.

The $A r$ mRNA levels in the kidneys of sham-operated mice were similar to those of orchidectomized mice, even after androgen treatment and subsequent bicalutamide treatment (Fig. 1B). Interestingly, the estrogen receptor $\alpha$ (Esr1) and progesterone receptor (Pgr) were clearly overexpressed in orchidectomized mice when compared to in sham-operated mice. In orchidectomized mice, DHT treatment significantly decreased Esr1 (Fig. 1C) or Pgr (Fig. 1D) mRNA levels in the kidney, when compared to in vehicle-treated or DHT-bicalutamide co-treated mice. This suggests that the DHT treatment induced androgen response transcripts and reduced estrogen response transcripts. It is generally accepted that estrogen induces $P G R$ mRNA and protein levels, and there is evidence that ESR1 binds the estrogen receptor response element (ERE) of the PGR gene (Petz et al. 2004). Likewise, Pgr level is controlled by $A r$ through its competition with activated estrogen receptor on ERE site in the Pgr promoter (Peters et al. 2009).

To determine whether DHT alters the expression of sex steroid hormone receptors, we conducted a separate set of experiments in which ESR1- and PGR-positive cell lines, T47D (Yu et al. 2017) and MCF7 cells (Levenson \& Jordan 1997), were incubated in medium depleted of steroids (i.e., containing $2 \%$ dextran charcoal-treated Printed in Great Britain
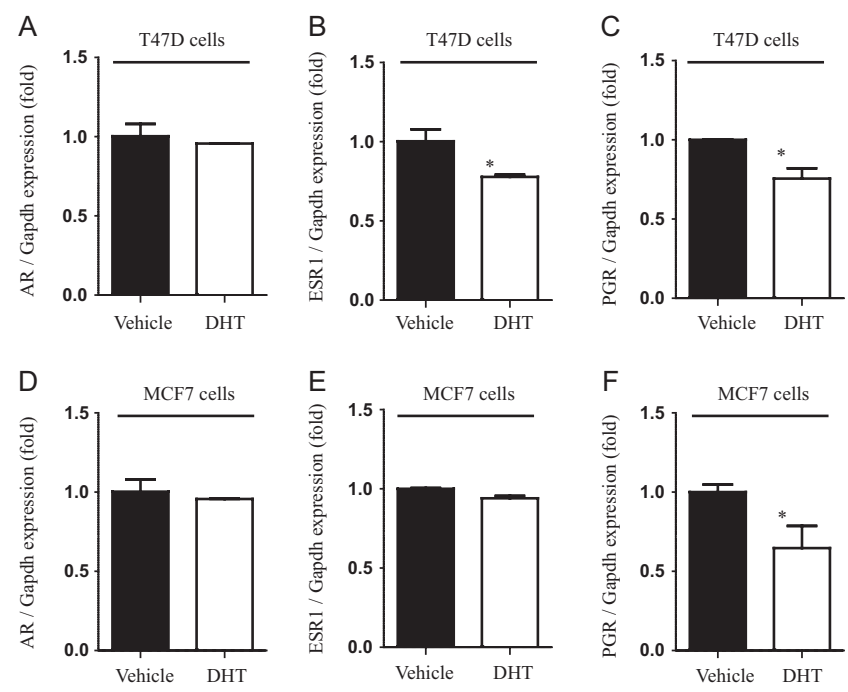

Figure 2

Influence of $5 \alpha$-dihydrotestosterone (DHT) on expression of sex steroid receptors in human hormone-dependent breast cancer cell. T47D or MCF-7 cells were treated with vehicle alone or with DHT, and AR (A and D), ESR1 ( $\mathrm{B}$ and $\mathrm{E}), P G R$ ( $\mathrm{C}$ and $\mathrm{F}$ ) mRNA levels were determined by quantitative RT-PCR. Cells were grown in phenol red-free DMEM/F12 medium supplemented with $2 \%$ charcoal-treated FBS for 5 days before daily treatments with DHT at $10 \mathrm{nM}$. GAPDH mRNA was used as in internal control. Values represent means \pm S.E.M. of three separate experiments, $P<0.05$ vs vehicle-alone (control)-treated group.

FBS) and supplemented with $10 \mathrm{nM}$ DHT. After $24 \mathrm{~h}, A R$ mRNA levels in DHT-treated cells were similar to those observed in vehicle-treated cells (Fig. 2A and D). More importantly, both ESR1 and PGR mRNA levels in DHTtreated cells decreased significantly when compared to those seen in vehicle-treated control cells (Fig. 2B, C and F). This observation raises the possibility that DHT suppresses PGR levels with and without the activity of estrogen receptor.

To validate the role of androgen receptor or estrogen receptor in $P G R$ expression, we examined the expression levels of PGR mRNA in ER $\alpha$-negative HEK 293 cells that had been transfected with cDNA constructs encoding the human androgen receptor or estrogen receptor $\alpha$. As expected, ERo-containing HEK 293 cells induced expression of the PGR mRNA, while PGR mRNA levels in $A R$-containing HEK 293 were not different from those in control-HEK 293 cells (Supplementary Fig. 1A, see section on supplementary data given at the end of this article). Although $A R$ can inhibit activation of target genes that mediate the stimulatory effects of $17 \beta$-estradiol on T47D cells (Peters et al. 2009), our result suggests that PGR inhibition is due to androgens and not $A R$-mediated signaling (Fig 2C and $\mathrm{F}$ and Supplementary Fig. 1A). While the PGR mRNA expression is decreased in HEK 
A

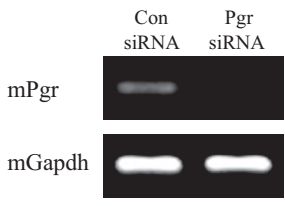

D

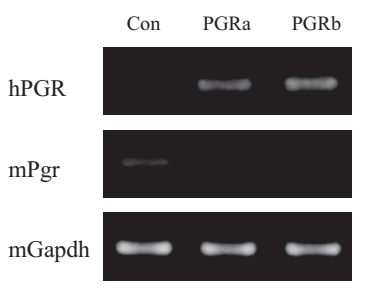

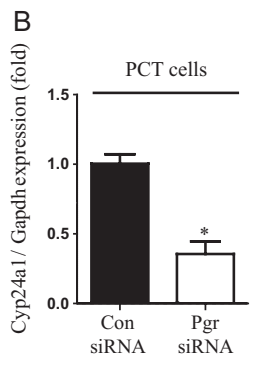

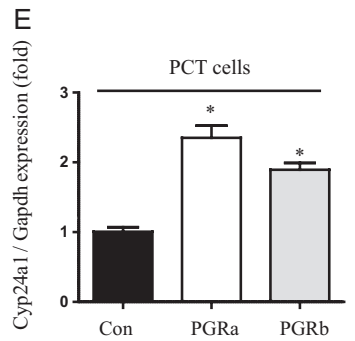

$\mathrm{C}$

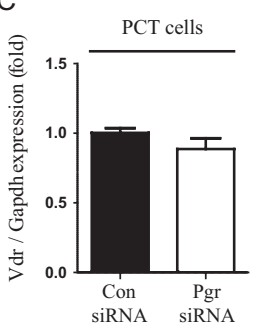

$\mathrm{F}$

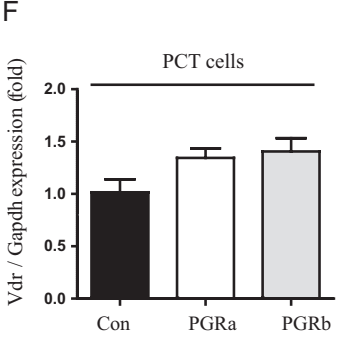

Figure 3

Impact of siRNA-mediated knockdown or PGR overexpression on the Cyp24a1 and Vdr mRNA expression. PCT cells were transfected with either $100 \mathrm{nM}$ control siRNA (con si) or progesterone receptor siRNA (Pgr si), and then cultured in medium containing $2 \% \mathrm{FBS}$ for a further $24 \mathrm{~h}(\mathrm{~A})$. Cyp24a1 (B), and $\operatorname{Vdr}(\mathrm{C})$ mRNA levels were determined by quantitative RT-PCR, using Gapdh mRNA as an internal control. The values represent means \pm S.E.M. of four experiments. $* P<0.05$ when $P G R$ siRNA treated PCT cells are compared to control siRNA treated PCT cells. PCT cells were transfected with PGRa or PGRb expression vectors, and then cultured in medium containing $2 \%$ FBS for a further $24 \mathrm{~h}(\mathrm{D}, \mathrm{m}=$ mouse, $\mathrm{h}=$ human). Cyp24a1 (E), and $V d r$ (F) mRNA levels were determined by quantitative RT-PCR, using Gapdh mRNA as an internal control. The values represent means \pm S.E.M. of four experiments. * $P<0.05$ when $P G R a$ or $P G R b$ expression vectors treated PCT cells are compared to control vector treated PCT cells.
293 cells following treatment with DHT (Supplementary Fig. 1B), AR mRNA levels were unchanged compared to those in vehicle-treated HEK 293 cells (Supplementary Fig. 1C). These results indicate that androgen-mediated Pgr suppression might be concerned with suppression of estrogen receptor.

\section{Progesterone receptor modulates Cyp24a1 expression in mouse proximal convoluted tubule (PCT) epithelial cells}

Modulation of sex steroid hormone receptors may occur in cells where sex steroids act in concert with vitamin $\mathrm{D}$ to influence important physiological events, such as calcium homeostasis (Van Cromphaut et al. 2003). To examine whether the loss of progesterone receptor in
PCT cells enhances or blocks the expression of vitamin D-related genes, Cyp24a1 and $V d r$, we depleted Pgr in PCT cells by treating them with a siRNA specific for Pgr mRNA (Fig. 3A). The siRNA treatment not only reduced $P g r$ mRNA levels, but also reduced Cyp24a1 mRNA levels in these cells (Fig. 3B). On the other hand, renal $V d r$ mRNA levels remained similar in PCT cells treated with PGR siRNA when compared to cells treated with control siRNA (Fig. 3C). When we increased PGR production in PCT cells by transfecting them with a vector expressing human PGR (Fig. 3D), we observed an increased expression of Cyp24a1 (Fig. 3E). However, $V d r$ mRNA levels were not significantly different in cells expressing human $P G R$ compared with cells that had been transfected with a control vector (Fig. 3F). These observations suggest that stimulation of $P G R$ activity

A

$10 \mathrm{~kb}$

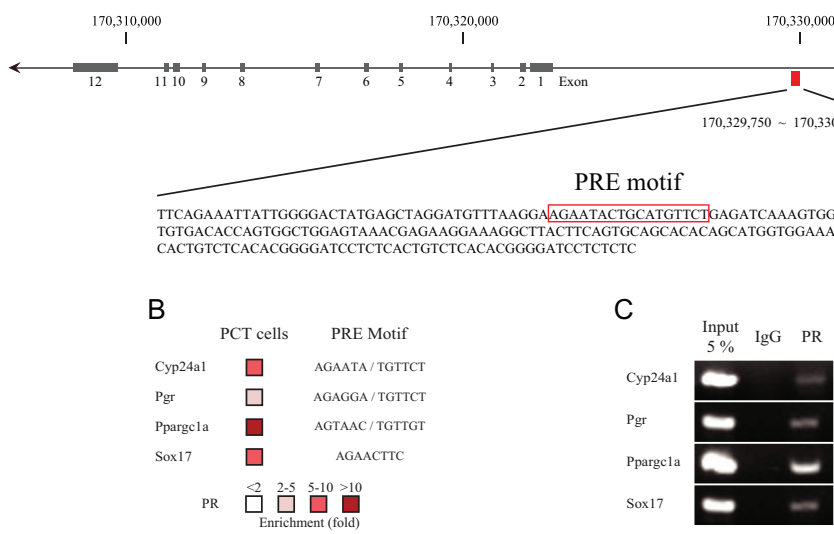

Cyp24a1 gene

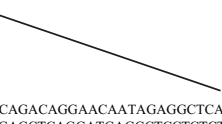

TCAGAAATTATTGGGGACTATGAGCTAGGATGTTTAAGGAAGAATACTGCATGTTCTGAGATCAAAGTGGTGGTGACAGACAGGAACAATAGAGGCTCA

http://jme.endocrinology-journals.org https://doi.org/10.1530/JME-17-0187

() 2018 Society for Endocrinology Published by Bioscientifica Ltd. Printed in Great Britain
Figure 4

Standard ChIP qPCR analysis of PGR occupancy on Cyp24a1 in the mouse PCT cell line. After PCT cells were cultured in medium containing $2 \%$ FBS for a further $24 \mathrm{~h}$, they were treated with $10 \mathrm{nM}$ progesterone for $1 \mathrm{~h}$, and then crosslinked by formaldehyde. The region of $P G R$ occupancy on Cyp24a1 gene is located 7775 bp upstream the transcription initiation site $(170,322,016$ in chromosome 2). The full palindromic PRE motif was indicated with red box (A). Pgr, Ppargc1a, and Sox17 gene promoter were introduced with positive control ( $B$ and $C$ ). A full color version of this figure is available at http://dx.doi. org/10.1530/JME-17-0187. 
A

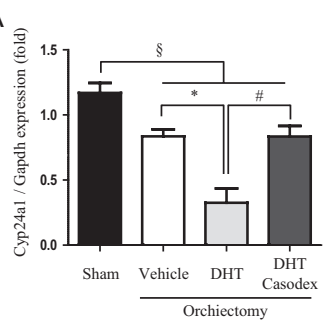

D

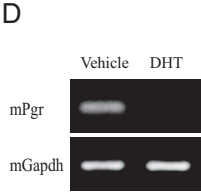

B

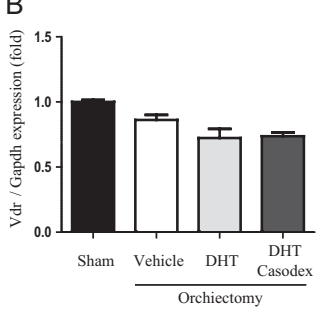

F

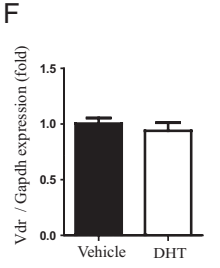

C

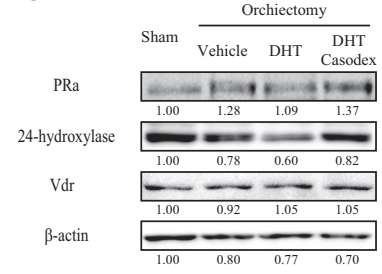

G

$$
\text { PRa }
$$

24-hydroxylase

VDR

$\beta$-actin

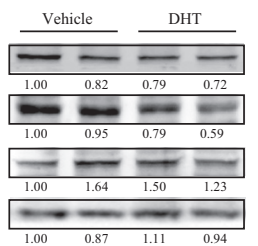

Figure 5

Influence of $5 \alpha$-dihydrotestosterone (DHT) on vitamin D-related genes. After orchiectomy and recovery of mice for 2 weeks, male mice were treated with vehicle alone (vehicle), with DHT ( $50 \mu \mathrm{g} /$ day) or DHT plus Bicalutamide $(1 \mathrm{mg} /$ day) for 5 days, and renal Cyp24a 1 (A), $\operatorname{Vdr}(\mathrm{B})$, and Cyp27b1 (C) mRNA levels were determined by quantitative RT-PCR. Gapdh mRNA was used as in internal control. Values represent means \pm S.E.M. ${ } P<0.05$ vs sham control group. ${ }^{*} P<0.05$ vs orchiectomy vehicle-alone (control) treated group. ${ }^{*} P<0.05$ vs DHT-bicalutamide treated group. In panel (D), the levels of renal CYP24A1, and VDR compared to PRa expression were analyzed by Western blotting. For these experiments, $40 \mu \mathrm{g}$ samples of protein extracts were analyzed, and $\beta$-ACTIN were also examined as internal controls. Relative amounts of protein expression in orchiectomy vs sham control was evaluated based on Western blot analysis. PCT cells were treated with vehicle alone (control) or with DHT, and Pgr mRNA levels were determined by RT-PCR (E), and Cyp24a 1 (F), and $V d r$ (G) mRNA levels were determined by quantitative RT-PCR. Cells were grown in phenol red-free DMEM/F12 medium supplemented with $2 \%$ charcoal-treated FBS for 5 days before daily treatments with DHT at $10 \mathrm{nM}$. Gapdh mRNA was used as in internal control. In panel (H), the levels of CYP24A1, and VDR in the corresponding PRa expression were assessed by Western blotting. For these experiments, $40 \mu \mathrm{g}$ samples of protein extracts were analyzed, and $\beta$-ACTIN were also examined as internal controls. The values represent means \pm S.E.M. of four experiments. ${ }^{*} P<0.05$ when DHT-treated PCT cells are compared to vehicletreated PCT cells. may result in increased Cyp24a1 expression in PCT cells. A recent ChIP sequencing (ChIP-seq) study using the mouse uterus identified binding events in the Pgr regulatory regions (Rubel et al. 2012). Therefore, we examined whether $10 \mathrm{nM}$ progesterone-treated PCT cells exhibit increased recruitment of $P G R$ to the progesterone response element (PRE) found in gene Cyp24a1 of mouse chromosome 2 (Fig. 4A). As shown in a previous study (Rubel et al. 2012), an enrichment in PGR binding was observed in the promoter regions of genes Pgr, Ppargc1a and Sox17. More importantly, the ChIP-seq experiment confirmed that $P G R$ was indeed recruited to a regulatory region in gene Cyp24a1 that contained the consensus progesterone response element, AGAATA/TGTTCT (Fig. 4B). As shown in Fig. $4 \mathrm{~B}$ and $\mathrm{C}$, binding of $P G R$ to this site was significantly augmented in progesteronetreated PCT cells. To validate this result, promoter regions of genes Pgr, Ppargc1a and Sox17 were introduced as positive controls in the PGR ChIP experiment (Fig. 4B and C). Our finding suggests that $P G R$ regulates
Cyp24a1 expression, and in turn, controls vitamin $\mathrm{D}_{3}$ 24-hydroxylase activity.

\section{DHT modulates the level of plasma 25-hydroxyvitamin D3 by progesterone-dependent Cyp24a1 expression}

Orchidectomized mice exhibited lower renal Cyp24a1 mRNA levels (Fig. 5A) when compared to sham-operated animal. More importantly, renal Cyp24a1 mRNA levels in orchidectomized mice were significantly decreased by DHT when compared to those in vehicle-treated mice or DHT-bicalutamide co-treated mice (Fig. 5A). On the other hand, renal $V d r$ mRNA levels were similar between DHT-treated mice and vehicle-treated mice (Fig. 5B). We further observed from Western blots that DHT treatment markedly decreased the abundance of renal 24-hydroxylase protein (Cyp24a1) relative to that of the vehicle-treated group (Fig. 5C). These observations suggest that the decreased renal PRa expression observed in DHT- 
A

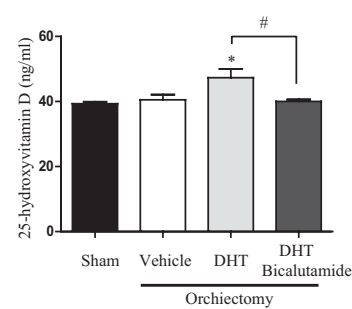

$B$
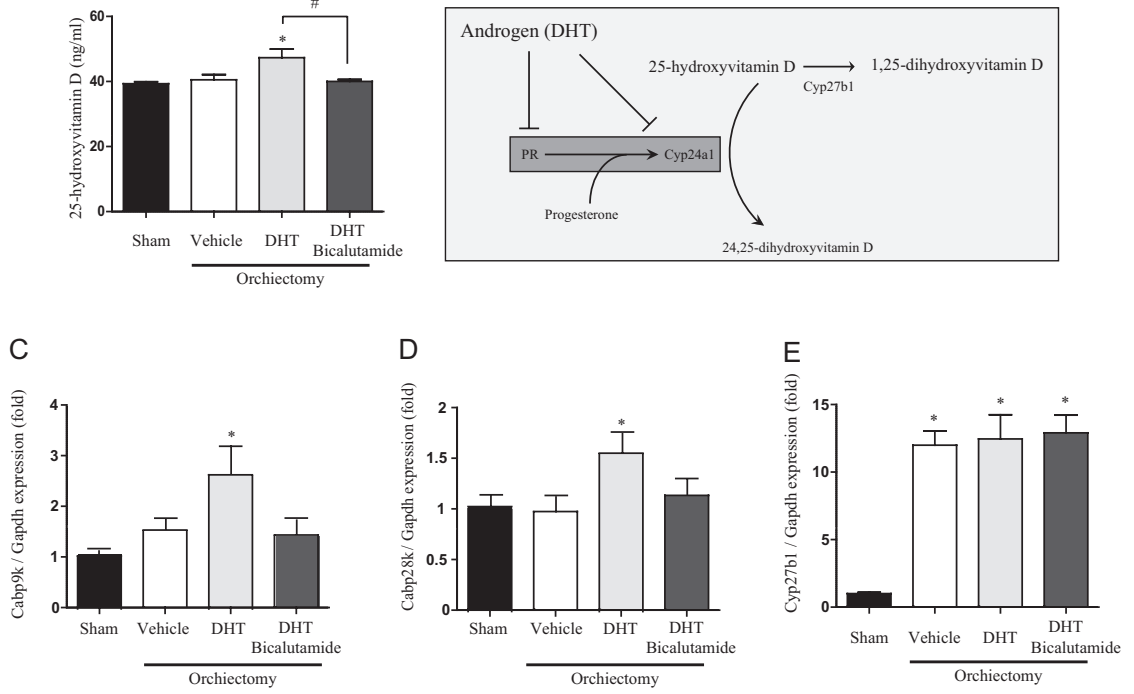

\section{Figure 6}

Influence of DHT to vitamin D and vitamin D-related genes expression. Level of 25-hydroxyvitamin $D$ in mouse serum is determined by enzyme-linked immunosorbent assay (A). Values represent means \pm S.E.M. ${ }^{*} P<0.05$ vs orchiectomy vehicle-alone (control) treated group. ${ }^{\# P}<0.05$ vs DHT-bicalutamide treated group. Schematic representation highlighting the molecular link between androgen (DHT), progesterone receptor, CYP24A1, and the vitamin D metabolites (B). Cabp9k and Cabp28k mRNA levels were determined by quantitative RT-PCR (C and D). Gapdh mRNA was used as in internal control. Values represent means \pm S.E.M. ${ }^{*} P<0.05$ vs sham control group. treated group may suppress 24-hydroxylase expression in orchidectomized mice (Fig. 5C). We cultured PCT cells in a medium depleted of steroids (i.e., containing $2 \%$ dextran charcoal-treated FBS) and then treated them in the same medium with and without $10 \mathrm{nM}$ DHT for $24 \mathrm{~h}$. Using mouse glyceraldehyde-3-phosphate dehydrogenase (Gapdh) as an internal standard, it was evident that Pgr mRNA levels were reduced in these cells after DHT treatment, as shown in Fig. 5D. Further comparison of DHT-treated PCT cells with vehicle-treated cells revealed a significant decrease in Cyp24a1 mRNA levels (Fig. 5E) and slight differences in $V d r$ mRNA levels (Fig. 5F). Parallel Western blot analyses showed that both progesterone receptor alpha (PRa) and 24-hydroxylase protein levels were suppressed in DHT-treated PCT cells when compared to those seen in vehicle-treated controls (Fig. 5G). These observations are consistent with the notion that an androgenic environment inhibits PRa expression, and this in turn suppresses 24-hydroxylase expression. To determine whether reduced 24-hydroxylase expression by DHT influences the levels of vitamin $\mathrm{D}_{3}$, we monitored plasma 25-hydroxyvitamin $\mathrm{D}_{3}$ in orchidectomized mice following treatment with DHT with and without bicalutamide for 5 days. We observed a significant increase in 25-hydroxyvitamin $\mathrm{D}_{3}$ in DHT-treated orchidectomized mice, as compared to that in corresponding vehicle-treated mice (Fig. 6A). In addition, co-treatment with bicalutamide almost completely blocked the DHT-stimulated increase in serum 25-hydroxyvitamin $\mathrm{D}_{3}$ (Fig. 6A), indicating that this stimulation must also be mediated by the androgen receptor, and this is linked with the previous results that show DHT regulating the expression of Pgr (Fig. 5E and $\mathrm{H})$ regardless presence of estrogen receptor. To summarize, our results demonstrate that androgen (DHT) signaling controls 24-hydroxylase degradation by regulating $\mathrm{Pgr}$ expression at the transcriptional and translational levels (Fig. 6B). It is also supported by induction of vitamin D-related genes, including Calbindin-9k and Calbindin28k mRNA levels (Fig. 6C and D), suggesting testosterone significantly increased in active vitamin D-response gene. We also observed significant increase in Cyp27b1 mRNA levels in all orchidectomized mice when compared to sham-operated animal (Fig. 6E). This observation is consistent with the notion that an administration of estradiol to males increased Cyp27b1 activity (Pike et al. 1978, Lechner et al. 2006).

\section{Discussion}

It is also established that androgen deficiency increases the risks of the common bone fractures associated with osteoporosis (Ross \& Small 2002, Alibhai et al. 2010). Androgen deprivation is a hallmark of prostate cancer therapy, but it is associated with side effects such as low serum 25-hydroxyvitamin $\mathrm{D}_{3}$ and osteoporosis (Diamond et al. 2004). In addition, there is a suggested evidence between radical orchidectomy and lower concentrations of 25-hydroxyvitamin $\mathrm{D}_{3}$ (Foresta et al. 2010). In light of the importance of androgen in male reproduction and its link with vitamin D, which is a global regulator of calcium uptake and is implicated in osteoporosis and various types of cancer, we sought to investigate the role of androgen in the biosynthesis and metabolism of vitamin $\mathrm{D}$.

Kidney androgen-regulated protein (Kap) gene is one of the most well-studied targets of androgen action in the mouse kidney (Toole etal. 1979, Meseguer \& Catterall 1990). 
Ourstudiesrevealed thatDHT treatmentoforchidectomized mice increased mRNA levels of androgen-responsive Kap when compared to those of vehicle-treated mice. Renal Kap gene expression is restricted to the PCT cells where it is more sensitive to androgen induction than other androgen-regulated genes, evidently because testosterone fails to induce Kap expression in Tfm/y Ar-deficient mice (Meseguer \& Catterall 1990). While DHT-stimulated Kap expression at the transcriptional level, treatment of DHT had the opposite effect on Esr1 and Pgr expression in the mouse kidney (Petz et al. 2004, Peters et al. 2009). In vitro analysis showed that DHT exposure significantly decreased the expression of ESR1 and PGR transcripts in breast cancer cells (T47D and MCF7) expressing estrogen, androgen and progesterone receptors. These findings are particularly interesting in light of reports that DHT treatment induced the activity of androgen receptor and reduced the expression of progesterone receptors in T47D cells (Liberato et al. 1993). Furthermore, there is evidence that testosterone suppressed ESR1 expression in mammary glands of non-human primates (Poulin et al. 1989, Zhou et al. 2000, Dimitrakakis et al. 2003). Moreover, early studies reported that the $P G R$ is regulated by estrogen in breast cancer cells (Nardulli et al. 1988, Read et al. 1988). It is now known that the $P G R$ gene contains estrogen response element site in its promoter region (Petz et al. 2004) and that its expression can be regulated indirectly by estrogen receptor-mediated effects (Petz et al. 2002). Recent studies have demonstrated that the $P G R$ is regulated by the activity of the androgen receptor, which interacts with an ERE in the PGR promoter (Peters et al. 2009).

The kidney is a site for $P G R$ expression in humans, and both $P G R$ transcripts and protein are detected in the renal cortex (Bumke-Vogt et al. 2002). To further define the role of $P G R$ in renal function, we used an immortalized mouse PCT cells, which is responsible for activation of sex steroid hormones (Meseguer \& Catterall 1987) or sex hormone-binding globulin (Hong et al. 2011). After treatment with $P g r$-specific siRNA in PCT cells, the corresponding Pgr deficiency was also accompanied by decreased Cyp24a1 mRNA levels when compared to those seen with control siRNA treatment. The correlation between Pgr and Cyp24a1 levels in PCT cells was evaluated following transfection with the $P R a$ or $P R b$ expression plasmids. In the context of vitamin D metabolism, the presence of the $P G R$ was found to enhance Cyp24a1 expression, which encodes the vitamin D-inactivating enzyme, 24-hydroxylase. Reduced levels of Cyp24a1 mRNA were observed in the kidney of DHT-treated orchidectomized mice and in DHT-treated PCT cells. DHT has been previously

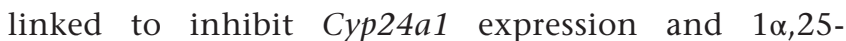
dihydroxyvitamin $\mathrm{D}_{3}$ catabolism (Lou et al. 2005), and physiological concentration of DHT has been shown to suppress the anti-proliferation effect of $1 \alpha, 25$ dihydroxyvitamin $\mathrm{D}_{3}$ in LNCaP cells (Zhao et al. 1997). Since DHT did not alter the basal level of Cyp24a1 mRNA in LNCaP cells and the 24-hydroxylase gene does not have androgen response element (ARE) in promoter region, DHT indirectly suppresses in Cyp24a1 expression through DNA-independent inhibition (Lou et al. 2005). While Cyp24a1 expression in PCT cells was significantly decreased by treatment with DHT, the relative amount of the $P G R$ was consistently lower in DHT-treated PCT cells. The latter is important because $P G R$, which represents genes directly inhibited by DHT, is involved in the regulation of transcription and cellular function (Li et al. 2003). These observations address the obvious question of whether progesterone receptor in the kidney restricts or enhances renal functions such as mineral absorption and hormone production.

Like other steroid hormone receptors, PGR also contains a DNA-binding domain for specific progesteroneresponsive element DNA sequences on putative target genes (Mangelsdorf et al. 1995). Cyp24a1 expression is controlled by suppression of PGR levels via DHT. We provide evidence that the loss of $P G R$ transcripts results in reduced renal 24-hydroxylase, which catabolizes 25-dihydroxyvitamin $\mathrm{D}_{3}$. Recent ChIP sequencing studies have reported PGR-binding events in the regulatory regions of various transcriptional factors in the murine uterus, as well as the presence of a canonical palindromic steroid receptor hormone response element, AGAACAnnnTGTTCT (Umesono \& Evans 1989, Rubel et al. 2012). Using ChIP sequencing in renal PCT cells, we confirmed that $P G R$ was indeed recruited to the gene Cyp24a1, or more specifically, to the regulatory region of this gene that contained the consensus progesterone response element, AGAATACTGCATGTTCT. Accordingly, we observed that DHT inhibited the expression of Cyp24a1 mRNA and 24-hydroxylase by PR-mediated action. Although we considered physiological relevance like estrogen-induced PGR, it is clear that androgen predominantly exists over estrogen in male. PGR and ESR1 under condition of androgenic inhibition could be linked with bone strength by activated vitamin $\mathrm{D}$ (Vanderschueren et al. 2014).

Calcitriol regulates its own metabolism by stimulating renal Cyp24a1 while it suppresses renal Cyp27b1 (Bikle 
2014). Since surgical orchiectomy reduced plasma 1 $\alpha, 25$-dihydroxyvitamin $\mathrm{D}_{3}$ and testosterone restored orchiectomy effects (Nyomba et al. 1987), the reduced calcitriol was related with low CYP24A1 expression (Jones et al. 1998). In present study, orchidectomized mice exhibited lower renal Cyp24a1 mRNA levels and higher Cyp27b1 mRNA levels when compared to shamoperated animal. Based on the results, it is possible that the orchidectomized mice might have low calcitriol level, and that the reduced calcitriol might reflect low levels of Cyp24a1 mRNA. In orchiectomy condition with low levels of calcitriol, DHT treatment additionally suppressed the renal Cyp24a1 mRNA levels. This is a particularly interesting evidence that the level of 25-hydroxyvitamin $\mathrm{D}_{3}$ increased under conditions where the supply for DHT is present, and that the increased levels was restored by bicalutamide. As reported in several previous studies, the serum concentrations of calcitriol decreased after orchiectomy in male rats and were restored by treatment with testosterone (Tanaka et al. 1976, Pike et al. 1978). Accordingly, the possibility exists that the DHT-induced 25-hydroxyvitamin $\mathrm{D}_{3}$ might be converted to calcitriol because of DHT-mediated 24-hydroxylase suppression. This is also relevant with previous findings that have shown male kidneys in other species preferentially hydroxylate 25-hydroxyvitamin $\mathrm{D}_{3}$ using 24-hydroxylase rather than 25-hydroxyvitamin $\mathrm{D}_{3}$-1-alpha hydroxylase (Pike et al. 1978). While androgen action suppressed the 24-hydroxylase expression, the androgen withdrawal could preferentially hydroxylate 25-hydroxyvitamin $\mathrm{D}_{3}$ to 24,25-hydroxyvitamin $\mathrm{D}_{3}$.

24-hydroxylase has been previously implicated in vitamin D homeostasis, which is evident from the low levels of vitamin D seen in Cyp24a1 transgenic rat (Hosogane et al. 2003) and the slow clearance of exogenous 25-dihydroxyvitamin $\mathrm{D}_{3}$ in Cyp24a1-null mice (Masuda et al. 2005). In agreement with several other studies (Hosogane et al. 2003, Lou et al. 2005, Masuda et al. 2005), we also expect androgen to enhance vitamin D-mediated functions by suppressing CYP24A1 expression. Using the vitamin D-response gene including Calbindin-9k and Calbindin-28K, we confirm the bioconversion into calcitriol in DHT-induced 25-hydroxyvitamin $\mathrm{D}_{3}$ increased condition. Although it has recently become apparent that both protein are not required for the uptake of calcium absorption (Koo et al. 2012), the evidence for the vitamin D-dependent uptake of calcium are well described as indicator of plasma vitamin D level (Belkacemi et al. 2005, Hong \& Jeung 2013). This is demonstrated in induction of vitamin D-response genes by DHT exposure.
The results presented in our report indicate that androgen deficiency within renal function acts to enhance 24-hydroxylase expression and suppresses the actions of vitamin D, especially under conditions of limited supply of androgens. These findings uncover an important role for androgen in vitamin $\mathrm{D}$ homeostasis and suggest that therapeutic modulation of progesterone receptor may be used to treat vitamin D deficiency and related disorders.

\section{Supplementary data}

This is linked to the online version of the paper at https://doi.org/10.1530/ JME-17-0187.

\section{Declaration of interest}

The authors declare that there is no conflict of interest that could be perceived as prejudicing the impartiality of the research reported.

\section{Funding}

This research was supported by Basic Science Research Program through the National Research Foundation of Korea (NRF) funded by the Ministry of Education (2013R1A1A2057648 and 2015R1D1A1A01060335 to E-J H). This work was also supported by research fund of Chungnam National University.

\section{References}

Alibhai SM, Duong-Hua M, Cheung AM, Sutradhar R, Warde P, Fleshner NE \& Paszat L 2010 Fracture types and risk factors in men with prostate cancer on androgen deprivation therapy: a matched cohort study of 19,079 men. Journal of Urology 184 918-923. (https://doi.org/10.1016/j.juro.2010.04.068)

Bardin CW \& Catterall JF 1981 Testosterone: a major determinant of extragenital sexual dimorphism. Science 211 1285-1294. (https://doi. org/10.1126/science.7010603)

Belkacemi L, Zuegel U, Steinmeyer A, Dion JP \& Lafond J 2005 Calbindin-D28k (CaBP28k) identification and regulation by 1,25-dihydroxyvitamin D3 in human choriocarcinoma cell line JEG3. Molecular and Cellular Endocrinology 236 31-41. (https://doi. org/10.1016/j.mce.2005.03.002)

Berger FG \& Watson G 1989 Androgen-regulated gene expression. Annual Review of Physiology 51 51-65. (https://doi.org/10.1146/ annurev.ph.51.030189.000411)

Bieche I, Narjoz C, Asselah T, Vacher S, Marcellin P, Lidereau R, Beaune P \& de Waziers I 2007 Reverse transcriptase-PCR quantification of mRNA levels from cytochrome (CYP)1, CYP2 and CYP3 families in 22 different human tissues. Pharmacogenetics and Genomics 17 731-742. (https://doi.org/10.1097/ FPC.0b013e32810f2e58)

Bikle DD 2014 Vitamin D metabolism, mechanism of action, and clinical applications. Chemical Biology 21 319-329. (https://doi. org/10.1016/j.chembiol.2013.12.016)

Bumke-Vogt C, Bahr V, Diederich S, Herrmann SM, Anagnostopoulos I, Oelkers W \& Quinkler M 2002 Expression of the progesterone receptor and progesterone- metabolising enzymes in the female and male human kidney. Journal of Endocrinology 175 349-364. (https:// doi.org/10.1677/joe.0.1750349)

Cartier N, Lacave R, Vallet V, Hagege J, Hellio R, Robine S, Pringault E, Cluzeaud F, Briand P, Kahn A, et al. 1993 Establishment of renal 
proximal tubule cell lines by targeted oncogenesis in transgenic mice using the L-pyruvate kinase-SV40 (T) antigen hybrid gene. Journal of Cell Science 104 695-704.

Catterall JF, Kontula KK, Watson CS, Seppanen PJ, Funkenstein B, Melanitou E, Hickok NJ, Bardin CW \& Janne OA 1986 Regulation of gene expression by androgens in murine kidney. Recent Progress in Hormone Research 42 71-109. (https://doi.org/10.1016/B978-0-12571142-5.50006-9)

Deeb KK, Trump DL \& Johnson CS 2007 Vitamin D signalling pathways in cancer: potential for anticancer therapeutics. Nature Reviews Cancer 7 684-700. (https://doi.org/10.1038/nrc2196)

Diamond TH, Bucci J, Kersley JH, Aslan P, Lynch WB \& Bryant C 2004 Osteoporosis and spinal fractures in men with prostate cancer: risk factors and effects of androgen deprivation therapy. Journal of Urology 172 529-532. (https://doi.org/10.1097/01.ju.0000130508.61020.66)

Dimitrakakis C, Zhou J, Wang J, Belanger A, LaBrie F, Cheng C, Powell D \& Bondy C 2003 A physiologic role for testosterone in limiting estrogenic stimulation of the breast. Menopause 10 292-298. (https:// doi.org/10.1097/01.GME.0000055522.67459.89)

Foresta C, Selice R, Di Mambro A \& Strapazzon G 2010 Testiculopathy and vitamin D insufficiency. Lancet 376 1301. (https://doi. org/10.1016/S0140-6736(10)61916-2)

Foresta C, Strapazzon G, De Toni L, Perilli L, Di Mambro A, Muciaccia B, Sartori L \& Selice R 2011 Bone mineral density and testicular failure: evidence for a role of vitamin D 25-hydroxylase in human testis. Journal of Clinical Endocrinology and Metabolism 96 E646-E652. (https://doi.org/10.1210/jc.2010-1628)

Greenspan SL, Coates P, Sereika SM, Nelson JB, Trump DL \& Resnick NM 2005 Bone loss after initiation of androgen deprivation therapy in patients with prostate cancer. Journal of Clinical Endocrinology and Metabolism 90 6410-6417. (https://doi. org/10.1210/jc.2005-0183)

Hong EJ \& Jeung EB 2013 Biological significance of calbindin-D9k within duodenal epithelium. International Journal of Molecular Sciences 14 23330-23340. (https://doi.org/10.3390/ijms141223330)

Hong EJ, Sahu B, Janne OA \& Hammond GL 2011 Cytoplasmic accumulation of incompletely glycosylated SHBG enhances androgen action in proximal tubule epithelial cells. Molecular Endocrinology 25 269-281. (https://doi.org/10.1210/me.2010-0483)

Hong EJ, Levasseur MP, Dufour CR, Perry MC \& Giguere V 2013 Loss of estrogen-related receptor alpha promotes hepatocarcinogenesis development via metabolic and inflammatory disturbances. PNAS 110 17975-17980. (https://doi.org/10.1073/pnas.1315319110)

Hosogane N, Shinki T, Kasuga H, Taketomi S, Toyama Y \& Suda T 2003 Mechanisms for the reduction of 24,25-dihydroxyvitamin D3 levels and bone mass in 24-hydroxylase transgenic rats. FASEB Journal 17 737-739. (https://doi.org/10.1096/fj.02-0965fje)

Iida K, Shinki T, Yamaguchi A, DeLuca HF, Kurokawa K \& Suda T 1995 A possible role of vitamin $\mathrm{D}$ receptors in regulating vitamin $\mathrm{D}$ activation in the kidney. PNAS 92 6112-6116. (https://doi. org/10.1073/pnas.92.13.6112)

Johnson LK, Hofso D, Aasheim ET, Tanbo T, Holven KB, Andersen LF, Roislien J \& Hjelmesaeth J 2012 Impact of gender on vitamin D deficiency in morbidly obese patients: a cross-sectional study. European Journal of Clinical Nutrition 66 83-90. (https://doi. org/10.1038/ejcn.2011.140)

Jones G, Strugnell SA \& DeLuca HF 1998 Current understanding of the molecular actions of vitamin D. Physiological Reviews 78 1193-1231. (https://doi.org/10.1152/physrev.1998.78.4.1193)

Kasperk CH, Wergedal JE, Farley JR, Linkhart TA, Turner RT \& Baylink DJ 1989 Androgens directly stimulate proliferation of bone cells in vitro. Endocrinology 124 1576-1578. (https://doi.org/10.1210/endo124-3-1576)

Koo TH, Yang H, An BS, Choi KC, Hyun SH \& Jeung EB 2012 Calcium transport genes are differently regulated in maternal and fetal placenta in the knockout mice of calbindin-D(9k) and -D(28k).
Molecular Reproduction and Development 79 346-355. (https://doi. org $/ 10.1002 / \operatorname{mrd} .22033)$

Kousteni S, Bellido T, Plotkin LI, O'Brien CA, Bodenner DL, Han L, Han K, DiGregorio GB, Katzenellenbogen JA, Katzenellenbogen BS, et al. 2001 Nongenotropic, sex-nonspecific signaling through the estrogen or androgen receptors: dissociation from transcriptional activity. Cell 104 719-730. (https://doi.org/10.1016/S00928674(02)08100-X)

Kurokawa K, Torikai S, Wang MS, Klein KL \& Kawashima H 1982 Metabolic heterogeneity of the nephron. Mineral and Electrolyte Metabolism 7 225-236.

Kwiecinski GG, Petrie GI \& DeLuca HF 1989 Vitamin D is necessary for reproductive functions of the male rat. Journal of Nutrition $\mathbf{1 1 9}$ 741-744. (https://doi.org/10.1093/jn/119.5.741)

Lechner D, Bajna E, Adlercreutz H \& Cross HS 2006 Genistein and 17beta-estradiol, but not equol, regulate vitamin D synthesis in human colon and breast cancer cells. Anticancer Research $\mathbf{2 6}$ 2597-2603.

Levenson AS \& Jordan VC 1997 MCF-7: the first hormone-responsive breast cancer cell line. Cancer Research 57 3071-3078.

Li X, Wong J, Tsai SY, Tsai MJ \& O'Malley BW 2003 Progesterone and glucocorticoid receptors recruit distinct coactivator complexes and promote distinct patterns of local chromatin modification. Molecular and Cellular Biology 23 3763-3773. (https://doi.org/10.1128/ MCB.23.11.3763-3773.2003)

Liberato MH, Sonohara S \& Brentani MM 1993 Effects of androgens on proliferation and progesterone receptor levels in T47D human breast cancer cells. Tumor Biology 14 38-45. (https://doi. org/10.1159/000217823)

Lou YR, Nazarova N, Talonpoika R \& Tuohimaa P 2005 5alphadihydrotestosterone inhibits 1alpha,25-dihydroxyvitamin D3-induced expression of CYP24 in human prostate cancer cells. Prostate 63 222-230. (https://doi.org/10.1002/pros.20189)

Mangelsdorf DJ, Thummel C, Beato M, Herrlich P, Schutz G, Umesono K, Blumberg B, Kastner P, Mark M, Chambon P, et al. 1995 The nuclear receptor superfamily: the second decade. Cell $\mathbf{8 3}$ 835-839. (https://doi.org/10.1016/0092-8674(95)90199-X)

Masuda S, Byford V, Arabian A, Sakai Y, Demay MB, St-Arnaud R \& Jones G 2005 Altered pharmacokinetics of 1alpha,25dihydroxyvitamin D3 and 25-hydroxyvitamin D3 in the blood and tissues of the 25-hydroxyvitamin D-24-hydroxylase (Cyp24a1) null mouse. Endocrinology 146 825-834. (https://doi.org/10.1210/en.20041116)

Meseguer A \& Catterall JF 1987 Mouse kidney androgen-regulated protein messenger ribonucleic acid is expressed in the proximal convoluted tubules. Molecular Endocrinology 1 535-541. (https://doi. org/10.1210/mend-1-8-535)

Meseguer A \& Catterall JF 1990 Cell-specific expression of kidney androgen-regulated protein messenger RNA is under multihormonal control. Molecular Endocrinology 4 1240-1248. (https://doi. org/10.1210/mend-4-8-1240)

Morris HA, O'Loughlin PD \& Anderson PH 2010 Experimental evidence for the effects of calcium and vitamin D on bone: a review. Nutrients 2 1026-1035. (https://doi.org/10.3390/nu2091026)

Nardulli AM, Greene GL, O'Malley BW \& Katzenellenbogen BS 1988 Regulation of progesterone receptor messenger ribonucleic acid and protein levels in MCF-7 cells by estradiol: analysis of estrogen's effect on progesterone receptor synthesis and degradation. Endocrinology 122 935-944. (https://doi.org/10.1210/endo-122-3-935)

Nyomba BL, Bouillon R \& De Moor P 1987 Evidence for an interaction of insulin and sex steroids in the regulation of vitamin $\mathrm{D}$ metabolism in the rat. Journal of Endocrinology 115 295-301. (https:// doi.org/10.1677/joe.0.1150295)

Peters AA, Buchanan G, Ricciardelli C, Bianco-Miotto T, Centenera MM, Harris JM, Jindal S, Segara D, Jia L, Moore NL, et al. 2009 Androgen receptor inhibits estrogen receptor-alpha activity and is prognostic 
in breast cancer. Cancer Research 69 6131-6140. (https://doi. org/10.1158/0008-5472.CAN-09-0452)

Petz LN, Ziegler YS, Loven MA \& Nardulli AM 2002 Estrogen receptor alpha and activating protein-1 mediate estrogen responsiveness of the progesterone receptor gene in MCF-7 breast cancer cells. Endocrinology 143 4583-4591. (https://doi.org/10.1210/en.2002-220369)

Petz LN, Ziegler YS, Schultz JR, Kim H, Kemper JK \& Nardulli AM 2004 Differential regulation of the human progesterone receptor gene through an estrogen response element half site and Sp1 sites. Journal of Steroid Biochemistry and Molecular Biology 88 113-122. (https://doi. org/10.1016/j.jsbmb.2003.11.008)

Pike JW, Spanos E, Colston KW, MacIntyre I \& Haussler MR 1978 Influence of estrogen on renal vitamin D hydroxylases and serum 1alpha,25$(\mathrm{OH}) 2 \mathrm{D} 3$ in chicks. American Journal of Physiology 235 E338-E343.

Poulin R, Simard J, Labrie C, Petitclerc L, Dumont M, Lagace L \& Labrie F 1989 Down-regulation of estrogen receptors by androgens in the ZR-75-1 human breast cancer cell line. Endocrinology 125 392-399. (https://doi.org/10.1210/endo-125-1-392)

Read LD, Snider CE, Miller JS, Greene GL \& Katzenellenbogen BS 1988 Ligand-modulated regulation of progesterone receptor messenger ribonucleic acid and protein in human breast cancer cell lines. Molecular Endocrinology 2 263-271. (https://doi.org/10.1210/mend-23-263)

Ross RW \& Small EJ 2002 Osteoporosis in men treated with androgen deprivation therapy for prostate cancer. Journal of Urology 167 1952-1956. (https://doi.org/10.1016/S0022-5347(05)65060-4)

Rubel CA, Lanz RB, Kommagani R, Franco HL, Lydon JP \& DeMayo FJ 2012 Research resource: genome-wide profiling of progesterone receptor binding in the mouse uterus. Molecular Endocrinology 26 1428-1442. (https://doi.org/10.1210/me.2011-1355)

Soler M, Tornavaca O, Sole E, Menoyo A, Hardy D, Catterall JF, Vandewalle A \& Meseguer A 2002 Hormone-specific regulation of the kidney androgen-regulated gene promoter in cultured mouse renal proximal-tubule cells. Biochemical Journal 366 757-766. (https://doi.org/10.1042/bj20011807)

Tanaka Y, Castillo L \& DeLuca HF 1976 Control of renal vitamin D hydroxylases in birds by sex hormones. PNAS 73 2701-2705. (https://doi.org/10.1073/pnas.73.8.2701)

Tannour-Louet M, Lewis SK, Louet JF, Stewart J, Addai JB, Sahin A, Vangapandu HV, Lewis AL, Dittmar K, Pautler RG, et al. 2014 Increased expression of CYP24A1 correlates with advanced stages of prostate cancer and can cause resistance to vitamin D3-based therapies. FASEB Journal 28 364-372. (https://doi.org/10.1096/fj.13-236109)

TooleJJ, NicholasD, HastieD, HeldWA 1979 An abundant androgenregulated mRNA in the mouse kidney. Cell 17 441-448. (https://doi. org/10.1016/0092-8674(79)90170-3)
Umesono K \& Evans RM 1989 Determinants of target gene specificity for steroid/thyroid hormone receptors. Cell 57 1139-1146. (https:// doi.org/10.1016/0092-8674(89)90051-2)

Van Cromphaut SJ, Rummens K, Stockmans I, Van Herck E, Dijcks FA, Ederveen AG, Carmeliet P, Verhaeghe J, Bouillon R \& Carmeliet G 2003 Intestinal calcium transporter genes are upregulated by estrogens and the reproductive cycle through vitamin D receptorindependent mechanisms. Journal of Bone and Mineral Research $\mathbf{1 8}$ 1725-1736. (https://doi.org/10.1359/jbmr.2003.18.10.1725)

Vanderschueren D, Laurent MR, Claessens F, Gielen E, Lagerquist MK, Vandenput L, Borjesson AE \& Ohlsson C 2014 Sex steroid actions in male bone. Endocrine Reviews 35 906-960. (https://doi.org/10.1210/ er.2014-1024)

Verdoia M, Schaffer A, Barbieri L, Di Giovine G, Marino P, Suryapranata H, De Luca G \& Novara Atherosclerosis Study G 2015 Impact of gender difference on vitamin D status and its relationship with the extent of coronary artery disease. Nutrition, Metabolism and Cardiovascular Diseases 25 464-470. (https://doi.org/10.1016/j. numecd.2015.01.009)

Watson G \& Paigen K 1988 mRNA synthesis rates in vivo for androgeninducible sequences in mouse kidney. Molecular and Cellular Biology 8 2117-2124. (https://doi.org/10.1128/MCB.8.5.2117)

Xue Y, Ying L, Horst RL, Watson G \& Goltzman D 2015 Androgens attenuate vitamin D production induced by UVB irradiation of the skin of male mice by an enzymatic mechanism. Journal of Investigative Dermatology 135 3125-3132. (https://doi.org/10.1038/ jid.2015.297)

Yu S, Kim T, Yoo KH \& Kang K 2017 The T47D cell line is an ideal experimental model to elucidate the progesterone-specific effects of a luminal A subtype of breast cancer. Biochemical and Biophysical Research Communications 486 752-758. (https://doi.org/10.1016/j. bbrc.2017.03.114)

Zhao XY, Ly LH, Peehl DM \& Feldman D 1997 1alpha,25dihydroxyvitamin D3 actions in LNCaP human prostate cancer cells are androgen-dependent. Endocrinology 138 3290-3298. (https://doi. org/10.1210/endo.138.8.5328)

Zhou J, Ng S, Adesanya-Famuiya O, Anderson K \& Bondy CA 2000 Testosterone inhibits estrogen-induced mammary epithelial proliferation and suppresses estrogen receptor expression. FASEB Journal 14 1725-1730. (https://doi.org/10.1096/fj.99-0863com)

Zhu JG, Ochalek JT, Kaufmann M, Jones G \& Deluca HF 2013 CYP2R1 is a major, but not exclusive, contributor to 25-hydroxyvitamin D production in vivo. PNAS 110 15650-15655. (https://doi. org/10.1073/pnas.1315006110)

Zumoff B 1982 Relationship of obesity to blood estrogens. Cancer Research 42 3289s-3294s.

Received in final form 10 December 2017

Accepted 22 December 2017 